\title{
Pentru o istorie comparată a Alsaciei și a Transilvaniei ${ }^{\dagger}$
}

\author{
Valentin Trifescu* \\ Facultatea de Litere, Universitatea „Alexandru Ioan Cuza”, Bd. Carol I 11, 700506 Iaşi, România
}

\section{Despre articol}

Istoric:

Primit 6 mai 2014

Acceptat 3 iunie 2014

Publicat 13 ianuarie 2015

Cuvinte-cheie:

Alsacia

Transilvania

analiză comparată

\begin{abstract}
Rezumat
Alsacia și Transilvania reprezintă două provincii istorice de frontieră, intens disputate de-a lungul istoriei, care au fost mereu puse în legătură, atît în discursul politicienilor, cît și în cel al intelectualilor sau al istoricilor. Prin articolul nostru dorim să facem o pledoarie pentru o istorie comparată între Alsacia şi Transilvania (ca două provincii de frontieră) și să aducem un prim set de argumente pentru această întreprindere științifică. Pornind de la avantajele și metodele de investigație ale istorie comparate, vom putea înțelege mai bine specificul identitar și modul în care aceste două provincii de margine s-au raportat la centrele lor de putere. În acest fel, istoria națională monolitică și exclusivă va fi înlocuită de o perspectivă fragmentară și/sau periferică, prin care vor ieși la lumină diferitele aspecte referitoare la: istoria locală sau regională, la regionalism sau la relația centru-periferie.
\end{abstract}

Pentru Jean-Noël Grandhomme

\section{Mitteleuropa de la Vosgi la Carpați}

Nenumărate sînt argumentele care pot fi invocate pentru realizarea unei istorii în care să fie comparate Alsacia și Transilvania. La fel de bine se pot găsi şi contraargumente, dintre acestea cel mai puternic fiind întrebarea contestatară, care ar diminua semnificativ importanţa subiectului ales: de ce Alsacia și Transilvania și nu Alsacia și Sicilia sau Alsacia și o regiune de pe planeta Marte? ${ }^{1}$

Metodologia de cercetare ridică probleme la fel de serioase, deoarece este foarte greu de a stabili în mod precis, după cum spunea Veyne (1999, p. 162), „unde începe istoria pur şi simplu [și] unde începe istoria comparată”; orice istoric fiind de fapt, la fel ca orice cercetător, un comparatist.

$\mathrm{Cu}$ toate acestea, mai multe sînt motivele care pledează pentru realizarea unei istorii în care să fie comparate Alsacia și Transilvania. O abordare în oglindă ne-ar permite observarea modului în care două provincii prin excelență de frontieră s-au raportat de-a lungul istoriei la centrele lor de putere. Pe de altă parte, vom putea analiza maniera în care politicile centralizatoare şi de asimilare au fost aplicate în cazul celor două regiuni de graniță intens disputate de Franța și de Germania, respectiv de România și de Ungaria. Nu în ultimul rînd, vom putea înțelege mai bine mecanizmele interioare care au determinat constituirea unei identități regionale de margine/frontieră, în contextul naționalismului din secolele al XIX-lea și al XX-lea.

Fără a avea sentimentul că forțăm noțiunea cultural-geografică de Mitteleuropa, considerăm că Transilvania și Alsacia sînt două regiuni istorice amplasate, pe axa Est-Vest, la o extremitate și la cealaltă a Europei

\footnotetext{
${ }^{\dagger}$ Această lucrare a fost finanțată din contractul POSDRU/159/1.5/S/140863, proiect strategic ID 140863 (2014), cofinanțat din Fondul Social European, prin Programul Operațional Sectorial Dezvoltarea Resurselor Umane 2007-2013.

*Adresă de corespondență: valentintrifescu@yahoo.fr.

${ }^{1}$ Pînă în prezent, după știința noastră, a apărut un volum colectiv în care au fost analizate Alsacia, Lorena, Trento și Trieste, în calitatea lor de regiuni de frontieră (vezi Ara \& Kolb, 1995, passim).
} 
Centrale $^{2}$, în care au coexistat mai multe națiuni și culturi, și în care lingua franca a fost (mai ales pentru elite), pînă la mijlocul secolului al XX-lea, limba germană (Le Rider, 2001, p. 121).

Pentru această Mitteleuropa de la Vosgi la Carpați pot fi invocate și argumente mai puțin științifice în sens clasic, dar care nu lasă indiferent un istoric ardelean care a luat contact cu Alsacia. Mai precis, istoria alimentaţiei ne vine în sprijin. Atît în Alsacia, cît și în Transilvania se cultivă prin excelență soiuri de vin $\mathrm{alb}^{3}$-specifice spațiului german și central european—, în timp ce în restul Franței și al României se cultivă mai ales soiuri de vin roșu. La fel de bine, o serie din specialităţile culinare tradiționale alsaciene ne amintesc de gustul mîncărurilor ardelenești.

Totodată, fără a avea pretenţia unui argument cu greutate, dar care poate fi convingător, putem să găsim în trecut și alte elemente, care ar sublinia destinul istoric comun al locuitorilor din Alsacia și din Transilvania, care le-ar așeza, ca într-un cerc închis, în Mitteleuropa. O parte dintre sașii colonizați în Transilvania evului mediu, care au realizat o adevărată infuzie civilizațională în interiorul arcului carpatic, au provenit de pe valea Rinului și a Moselei.

Toate temerile în legătură cu alegerea și mai ales cu justificarea subiectului unei cercetării comparate între Alsacia și Transilvania (Trifescu, 2013, passim) s-au spulberat în momentul în care am constatat că și cercetătorii maghiari sînt interesați de o asemenea temă și abordare metodologică ${ }^{4}$. Domnul Máté Rigó lucrează în momentul de față la o teză de doctorat în care și-a propus să pună cu prioritate accentul asupra problemelor economice și sociale din cele două regiuni de frontieră integrate pînă la sfîrșitul Primului Război Mondial în cadrul administrativ al Puterilor Centrale (Germania și Austro-Ungaria). În acest fel, se va completa în modul cel mai fericit, oferindu-se o perspectivă gnoseologică mai largă, intenția noastră de a înțelege specificul cultural și identitar al Alsaciei și al Transilvaniei, în calitatea lor de provincii de frontieră (Trifescu, 2010, p. 73-78; Trifescu, 2014, p. 59-70).

După toate aceste note introductive, trebuie amintit studiul de referință publicat de Marc Bloch (18861944), în 1928, unde au fost etalate beneficiile pe care le poate aduce istoria comparată cercetării științifice. În ceea ce privește metodologia, reputatul istoric de la Universitatea din Strasbourg aprecia, pe lîngă o serie întreagă de detalii semnificative, și faptul că scopul istoriei comparate nu este doar găsirea asemănărilor, ci și identificarea deosebirilor dintre societățile și spațiile luate în anchetă. Astfel,

"Qu'est-ce, tout d'abord, dans notre domaine, que comparer? Incontestablement ceci : faire choix, dans un ou plusieurs milieux sociaux différents, de deux ou plusieurs phénomènes qui paraissent, au premier coup d'œil, présenter entre eux certaines analogies, décrire les courbes de leurs évolutions, constater les ressemblances et les différences et, dans la mesure du possible, expliquer les uns et les autres. Donc deux conditions sont nécessaires pour qu'il y ait, historiquement parlant, une certaine similitude entre les faits observé-cela va de soi-et une certaine dissemblance entre les milieux où ils se sont produits [...]" (Bloch, 2006, p. 350) ${ }^{5}$.

Finalitatea întreprinderii comparatiste va fi, în cele din urmă, o mai bună recuperare și înțelegere a

\footnotetext{
${ }^{2}$ În sprijinul opiniei noastre vine considerația lui Jacques le Rider, care lasă să se înțeleagă același lucru, considerînd că Imperiul german și Imperiul habsburgic formează, începînd din epoca modernă, Mitteleuropa (vezi Le Rider, 2001, p. 109). În altă ordine de idei, geografi ca Joseph Partsch și Erwin Hanslik au fixat Mitteleuropa, în primele două decenii ale secolului al XX-lea, între coordonatele: Galați-Sofia-Sarajevo-Trieste și respectiv Danzig-Trieste-Odesa (vezi Droz, 1960, p. 17-18). Pentru diferitele definiții geografice, culturale, istorice și politice date Mitteleuropei, vezi Sinnhuber (1953, p. 15-39) și Droz (1960, passim).

${ }^{3}$ Despre istoria vinului în Alsacia şi despre modul cum acesta a imprimat un specific cultural și identitar regiunii, vezi Muller (2010, passim).

${ }^{4}$ Máté Rigó, Money, Reconstruction, Borderlands: social and economic restructuring in Alsace-Lorraine and Transylvania following World War I, (teză de doctorat în curs), Cornell University, Ithaca, Department of History.

5 „Ce înseamnă, înainte de toate, în domeniul nostru, a compara? Incontestabil aceasta: a alege, din cadrul unuia sau mai multe medii sociale diferite, două sau mai multe fenomene care par, la prima vedere, să aibă unele analogii între ele, a descrie curbele evoluției lor, a constata asemănările și deosebirile și, atît cît este posibil, a le explica. Sînt, aşadar, necesare două condiții ca să existe, istoric vorbind, o anumită similitudine între faptele observate—în mod firesc—și o anumită deosebire între mediile în care acestea au loc [...]".
} 
istoriei locale și regionale, în contextul în care se va aduce la lumină un al treilea discurs (discursul regional/regionalist), care va căpăta în anumite cazuri valoarea unei soluții viabile de dialog, opuse discursurilor tari naționale/naționaliste, caricaturale și incompatibile prin definiţie. În continuarea acestor idei, Marc Bloch a apreciat că:

„[...] L'histoire comparée, rendue plus aisée à connaître et à servir, animera de son esprit les études locales, sans lesquelles elle ne peut rien mais qui sans elle n'aboutiraient à rien. En un mot, cessons, si vous le voulez bien, de causer éternellement, d'histoire nationale à histoire nationale, sans nous comprendre. Un dialogue entre des sourds, dont chacun répond tout de travers aux questions de l'autre, c'est un vieil artifice de comédie, bien fait pour soulever les rires d'un public prompt à la joie ; mais ce n'est pas un exercice intellectuel bien recommandable" (Bloch, 2006, p. 380$)^{6}$.

\section{Paralelisme între „cazul alsacian” și „cazul transilvănean”}

Este binecunoscută cititorului nostru relația privilegiată pe care a avut-o România (inițial Principatele Române) cu Franța, în secolele al XIX-lea și al XX-lea, și impactul dominant și determinant pe care l-au avut cultura şi civilizația franceză în formarea tînărului stat carpato-dunăreano-pontic.

Raportarea intelectualilor români la Alsacia s-a făcut mai ales pentru rezolvarea situației naționale și regionale a Transilvaniei. „Cazul alsacian” a devenit, după terminarea războiului franco-prusac (18701871), unul paradigmatic pentru toată Europa. Mai precis, a fost vorba de Alsacia-Lorena, ca nouă provincie administrativă a Imperiului german, care simboliza prin excelență un teritoriu de profunde convulsii identitare și minoritare, reprezentînd în același timp și mărul de discordie dintre două națiuni în ofensivă.

Preluarea exemplului alsacian de către autoritățile române de după 1919 a fost atît de evidentă încît întemeierea sistemului de învățămînt superior românesc din Transilvania a fost realizată după „modelul Strasbourg”, aplicat de altfel și de cehoslovaci la Bratislava (Sălăgean, 2012, p. 128, 132). În urma propunerilor mai multor intelectuali români, dintre care s-au remarcat Nicolae Drăescu, Nicolae Drăganu și Onisifor Ghibu, Consiliul Dirigent a naționalizat vechea universitate maghiară din Cluj, așezînd-o pe baze românești. În același timp, încă de la început, s-a dorit ca noua instituție să nu fie animată de un spirit regionalist și particularist, „susținîndu-se, dimpotrivă, necesitatea integrării ei cît mai curînd posibil în sistemul universitar românesc" (Sălăgean, 2012, p. 128). Cu ocazia punerii în practică a acestor intenții, s-a realizat de fapt naţionalizarea sistemului de învățămînt superior din Transilvania, gestionîndu-se în acest fel formarea viitoarelor elite regionale în spiritul românist promovat de autoritățile centrale de la București. Cu toate acestea, au existat și alte propuneri în legătură cu modul în care să fie reorganizat învățămîntul superior din Transilvania, care nu au avut cîștig de cauză.

Cu ocazia vizitei cuplului regal al României la Paris, în aprilie 1924, s-au subliniat încă o dată interesele comune ale Franței și ale României în ceea ce privește integrarea noilor provincii în cadrul administrativ al statului național, precum și în ceea ce privește rezolvarea problemei revizionismului german și maghiar ${ }^{7}$.

${ }^{6}$ „[...] Istoria comparată, devenită mai ușor de cunoscut și de folosit, va însufleți studiile locale, fără de care ea nu poate nimic, dar care, fără ea, nu ar conduce la nimic. Într-un cuvînt, să încetăm, dacă doriți, să pălăvrăgim, de la o istorie națională la alta, fără să ne înțelegem. Un dialog între surzi, în care fiecare răspunde de-a curmezișul la întrebările celuilalt, e un vechi artificiu de comedie, perfect pentru a face să rîdă un public dornic de veselie, dar nu este un exercițiu intelectual foarte recomandabil”.

${ }^{7}$ În anii 1917-1918, după intrarea României în război pentru a cîștiga Transilvania, în Alsacia-Lorena au funcționat mai multe lagăre de prizonieri unde au fost aduși soldați din Armata Română, care au beneficiat de un tratament deosebit de sever, mai ales pentru faptul că România trecuse de partea Antantei. Cu ocazia inaugurării cimititului soldaților români de la Soultzmatt de către regele Ferdinand și regina Maria, la 9 aprilie 1924, grupul din Colmar și împrejurimi al „Union des pères et de mères dont les fils sont tombés” a adresat o scrisoare în care au fost subliniate legăturile și interesele comune pentru unitatea teritorială ale Franței și României: „Ils reposent, morts pour leurs Patrie, en terre amie, vénérés de tous, un soulagement pour leurs familles et leurs peuples. Ils méritent doublement notre reconnaissance, ayant aussi aidé dans cette grande tourmente à la délivrance de notre petite Patrie, l'Alsace-Lorraine! / El les Roumain enterrés dans notre pays ont droit qu’à leur cercueil la foule vienne et prie!" (vezi Nouzille, 1997, p. 64, coperta 4). 
După cum bine observa Jean-Noël Grandhomme, „Pour L'Indépendance roumaine cette visite imprévue revête une grosse importance politique. Les traités de 1919-1920, qui ont rendu l'Alsace et la Lorraine à la France, ont apporté l'unité nationale à la Romanie. L'intérêt des deux pays de sopposer à leur révision, réclamée par l'Allemagne et la Hongrie, afin de maintenir la paix en Europe [...]" (Grandhomme, 2000, p. 146) $)^{8}$. Cei doi monarhi au ținut în mod special ca, în drumul lor către Paris, să facă o primă oprire la Strasbourg, unde au fost întîmpinați de către autorităţile locale și de către locuitorii orașului cu tot fastul cuvenit unor înalți demnitari. Cu ocazia ceremoniilor de primire, regina Maria (1875-1938) a fost făcută, în calitatea ei de scriitoare, doctor honoris causa al Universității din Strasbourg (Grandhomme, 2000, p. 149; Grandhomme, 2011, p. 800). Înalta distincție academică acordată reginei României trebuie interpretată mai ales ca un act politic_care venea în acord cu politica oficială de Stat-făcut de universitarii francezi din Strasbourg. Semnificativ este însă și faptul că încă din 1919, imediat după ce francezii au naţionalizat Universitatea din Strasbourg, istoricul Nicolae Iorga (1871-1940) a fost numit doctor honoris causa (Grandhomme, 2000, p. 145), cunoscută fiind perspectiva sa naționalistă asupra istoriei românilor-mai ales a celor din Transilvania. În acest fel, înțelegem cu mult mai bine impactul pe care l-a avut modelul francez implementat în Alsacia pentru autoritățile române din Transilvania.

$\mathrm{Nu}$ doar românii au fost cei care s-au inspirat din modelul alsacian (Lorena a jucat întotdeauna un rol secundar în toată această discuție, la fel cum a fost cazul Banatului, care mereu a fost pus „la remorca” Transilvaniei) și din modul cum Franța a recuperat teritoriul dintre Vosgi și Rin. Raportarea a fost reciprocă. Într-o bună măsură, în discursul intelectualilor francezi și români, Alsacia(-Lorena) a devenit „Transilvania francezilor", iar Transilvania a devenit „Alsacia(-Lorena) românilor”.

Puțini au fost oamenii de cultură francezi care s-au preocupat, în secolul al XIX-lea, de soarta națională a românilor din cadrul Monarhiei austro-ungare. Transilvania românilor la acea epocă nu reprezenta un subiect de interes major pentru cultura și politica din Franța, situație datorată în bună măsură faptului că România regelui Carol I era încadrată sistemului politic și militar al Puterilor Centrale. Pînă la Primul Război Mondial, putem cita numele istoricului și profesorului Ernest Denis (1849-1921), care a acordat o atenție particulară românilor din Dubla Monarhie (Grandhomme, 1997, p. 223). De fapt, după cum observa Jean-Noël Grandhomme:

„La Guerre allait faire connaître la Transylvanie au public français, en la présentant, de façon très parlant, comme l'Alsace-Lorraine de la Roumanie. À partir de la signature de l'accord du 17 août 1916-qui consacre solennellement l'alliance entre la Roumanie et l'Entente-la France soutint officiellement le droit à la Roumanie d'annexer la Transylvanie" (Grandhomme, 1997, p. 223) ${ }^{9}$.

Pe lîngă Marele Război, și generalul Henri-Mathias Berthelot (1861-1931) a jucat un rol deosebit de important în rezolvarea „chestiunii alsaciene” din perspectiva oferită de cazul Transilvaniei românești. Cu siguranță, nu întîmplător, după terminarea misiunii sale din România, generalul Berthelot a fost numit guvernator militar la Metz, din octombrie 1919, și apoi guvernator militar la Strasbourg, din primăvara anului 1923 (Grandhomme, 2011, p. 737, 771). Dacă nu s-a dorit în mod concret sublinierea analogiei Alsacia-Transilvania de către autoritățile pariziene, cu siguranță, prin aducerea lui Berthelot la conducerea teritoriilor recuperate de la germani, administrația franceză a încercat să fructifice la maximum experiența acumulată de militarul de carieră într-o provincie istorică intens disputată şi revendicată, care ridica aceleaşi probleme identitare acute și presupunea, în acelaşi timp, o integrare administrativă anevoioasă în noile structuri naționale. În acest sens,

\section{„Berthelot découvre une ville et une région [Strasbourg și Alsacia n. n.] profondément modifiées}

\footnotetext{
${ }^{8}$ „Pentru Independența României, această vizită neprevăzută acoperă o mare importanță politică. Tratatele din 1919-1920, care i-au înapoiat Franței Alsacia și Lorena, i-au adus unitatea națională României. Interesul celor două țări în a se opune revizuirii acestora, revizuire cerută de Germania și de Ungaria, pentru a menține pacea în Europa [...]”.

${ }^{9}$ „Războiul urma să facă Transilvania cunoscută publicului francez, prezentînd-o, într-o manieră foarte orală, ca fiind Alsacia-Lorena României. Începînd cu semnarea acordului din 17 august 1916 — care consacră solemn alianța dintre România și Antanta-Franța a susținut dreptul României de a anexa Transilvania”.
} 
à tous points de vues par l'empreinte germanique, et qui s'efforcent de retrouver petit à petit leur caractère français. L'expérience du douloureux passage de la Transylvanie de la loi hongroise à la loi roumaine, dont il a étéle témoin sur place, promet de lui être bien utile [...]" (Grandhomme, 2011, p. 738$)^{10}$.

Atît în cercurile culturale, cît și în cercurile politico-diplomatice românești, modelul alsacian a fost mereu invocat pe parcursul secolului al XX-lea. Inclusiv după evenimentele din decembrie 1989, autorităţile românești-inclusiv președintele țării Ion Iliescu—au propus încheierea unui compromis istoric între România și Ungaria după „modelul franco-german” (Pomogáts, 2002, p. 200). Intenția părții românești a fost de fapt obținerea unui acord maghiar ireversibil pentru o Transilvanie integrată definitiv în componența Statului român, la fel cum s-a întîmplat cu Alsacia pentru cazul francez.

După cum observa istoricul și criticul literar Béla Pomogáts, mai ales din punctul de vedere maghiar, nu se poate face o analogie credibilă între Alsacia și Transilvania, ca două provincii de frontieră revendicate de către două state vecine. Potrivit lui Pomogáts:

„Istoria contradicțiilor maghiaro-române nu poate fi comparată cu istoria conflictelor francogermane, pentru că, în primul rînd, între cele două țări nu a existat niciodată o rivalitate pentru supremaţia regională. Odinioară, Ungaria era o parte a unei mari puteri europene, a Monarhiei habsburgice, iar în comparație cu această putere, România era o țară neînsemnată, care niciodată nu s-ar fi opus fățis monarhiei (ba mai mult pînă la primul război mondial a fost aliatul politic și militar al acesteia), iar după 1918, între cele două țări nici nu putea să existe o rivalitate, pentru că nici una dintre ele nu era o «putere centrală» regională. [...]” (Pomogáts, 2002, p. 201-202).

Motivațiile pe care se construiește argumentația istoricului literar maghiar sînt mai ales de natură istorică. Una dintre cauzele majore ale conflictului franco-german a fost reprezentată de problema rezolvării dreptului de proprietate asupra regiunii Alsacia-Lorena, teritoriu care a fost deținut pe rînd, cînd de francezi, cînd de germani. În schimb, situația nu este asemănătoare și pentru Transilvania-incluzînd aici Banatul şi Partium-ul—, care pînă la 1918 a fost doar sub stăpînire maghiară (excluzînd etapa austriacă) (Pomogáts, 2002, p. 200-201). Ca o alternativă cu mult mai credibilă, Béla Pomogáts a recomandat, pentru reconcilierea româno-maghiară din Transilvania, cazul austro-italian din Tirolul de Sud (sau Trentino Alto Adige), unde s-a realizat o autodeterminare a populației germanofone din regiune, în condițiile unui sprijin extern oferit de autoritățile din Austria (Pomogáts, 2002, p. 202).

\section{Prime comparații între Alsacia și Transilvania}

Cu toate că Primul Război Mondial a consacrat în cultura românească „chestiunea alsaciană” pentru cazul Transilvaniei-după cum am văzut mai sus, și „chestiunea transilvană” pentru cazul Alsaciei-, chiar din anul 1909 avem un studiu inedit și deosebit de important pentru subiectul cercetării noastre, în care a fost comparată Alsacia-Lorena cu Transilvania. Studiul îl datorăm lui Onisifor Ghibu (1883-1972), care în anul universitar 1907-1908 a venit un semestru la Facultatea de Litere și Filozofie din cadrul Universităţii din Strasbourg cu o bursă oferită de Societatea „Transilvania” (Sigmirean, 2000, p. 718) ${ }^{11}$.

Încă de la începutul articolului, care a fost dezvoltat de-a lungul a 59 de pagini, autorul și-a propus să vorbească cititorilor români despre ,unul dintre cele mai interesantepetece de pămînt din Europa”, care a fost pînă la acel moment puțin cunoscut românilor, și care a devenit totodată, în primul deceniu al secolului al XX-lea, „din nou arena unor lupte interesante între două popoare dintre cele mai culte și mai înduşmănite” (Ghibu, 1909, p. 3).

\footnotetext{
${ }^{10}$ „Berthelot descoperă un oraș și o regiune modificată pînă în profunzime din toate punctele de vedere de către amprenta germanică și care se străduiesc să-și regăsească, puțin cîte puțin, caracterul francez. Experiența trecerii dureroase a Transilvaniei de la legea ungară la legea română, al cărei martor ocular a fost, se anunță a-i fi foarte utilă [...]”

${ }^{11}$ Tot în acelaşi an universitar, Onisifor Ghibu a studiat un semestru și la Universitatea din Tübingen (Sigmirean, 2000, p. 719).
} 
Datorită preocupărilor sale pedagogice, Onisifor Ghibu a acordat o atenție prioritară aspectelor legate de viața școlară din Alsacia-Lorena-mai ales din zonele cu o populație francofonă majoritară-, care i-au servit, în cele din urmă, drept model de comparație pentru situația învățămîntului românesc din Transilvania.

Prin descrierea călătoriei sale în Alsacia-Lorena, intelectualul român a făcut și o serie de precizări importante în legătură cu situația identităților naționale şi regionale din Alsacia și Lorena, precum şi în legătură cu problemele lingvistice, politice, administrative, confesionale și culturale.

Onisifor Ghibu a prezentat Alsacia-Lorena în ipostaza unui teritoriu care lasă unui străin „cele mai contradictorii impresii”. Cel care ia contact pentru prima dată cu aceste regiuni istorice este bulversat mai întîi de nenumăratele discursuri și păreri, mai mult sau mai puțin oficiale, care dezvoltă punctul de vedere francez și punctul de vedere german asupra statutului celor două provincii istorice. „Dacă ai da crezămînt nețărmurit informațiilor germane, ai crede că aici totul s'a germanizat și că puținele resturi franceze nu reprezintă supt nici un raport ceva, iar dacă te-ai lua după informațiile franceze, uneori, evident, meșteșugitoptimiste, ai crede că, cel puțin în o mare măsură, aici totul e francez din fundament" (Ghibu, 1909, p. 4-5). În cele din urmă, autorul studiului nu se lasă sedus de nici una dintre teoriile naţionale, optînd pentru „calea de mijloc [care] pare cea adevărată”, în care se pot identifica atît progresele notabile ale germanizării cît și rezistențele vechilor tradiții franțuzești în fața elementelor de natură diferită venite de la Est de Rin (Ghibu, 1909, p. 5).

Cea mai puternică impresie, în urma căreia Alsacia și Lorena au fost descrise în calitatea lor de teritorii ale contrastelor, a fost determinată de realitatea demografică propriu-zisă. Pentru intelectualul ardelean, specificul aparte al acestor regiuni a fost dat de conviețuirea a două națiuni complet diferite, care, în plus, se duşmănesc de moarte, situație care ne trimite cu gîndul la Transilvania din care venea Onisifor Ghibu.

„[...] Căci aici pretutindeni ai a face cu două popoare fundamental opuse unul altuia prin firea lor, prin îndeletnicirile lor, prin felul de a ieși în lume și prin scopurile pe care le vor servi totdeauna în feluri diferite. Germanul stăruitor, cu un puternic simţ patriotic care răsuflă pretutindeni și în cele mai variate forme, uneori foarte jignitoare pentru alții, mîndru de marele nume german de azi, gata a-și sacrifica totul pentru înălțarea acestui nume, spirit asociaționist care arată lumei tot ce are, e cu totul diferit de Francezul sentimental, care-și trăiește din ce în ce mai mult viața pentru sine, care respectă patria mai mult din ambiție, care-și iubește limba mai mult fiindcă i-o iubesc și alții și pentrucă e frumoasă, decît pentrucă e a sa, și care oriunde ar fi, nu caută, ca Germanul, puterea în unire, ci în încredere și adevăr, în sfîrşit Francezul care și la el acasă ițî iese în cale mai mult ca un «magister elegantiarum» în ale vieții materiale, decît ca un stăruitor luptător pentru o idee care se realizează cu anevoie - acești doi dușmani care nu se vor împăca niciodată, aici în Alsacia-Lorena ți se prezintă între împrejurări care și pe cunoscători mai buni îi pot seduce" (Ghibu, 1909, p. 4).

După cum am văzut, au fost enumerate toate calitățile și defectele celor două națiuni, care au îmbrăcat în definitiv aspectul unor stereotipuri și prejudecăți.

Grila de lectură din care Onisifor Ghibu a analizat Alsacia-Lorena a fost cea a unui român ardelean din cadrul Monarhiei austro-ungare. Pentru el, a fost ciudat cum alsacienii și lorenii au acceptat administrația germană, fără mari rezistențe, mulțumindu-se cu o situație de compromis, prin care au obținut recunoașterea cîtorva drepturi culturale și administrative. Cele două provincii istorice au fost alcătuite, în viziunea intelectualului român, din francezi și germani, existența identităților regionale fiind percepută ca ceva neobişnuit și de neînțeles. Cu toate acestea, Ghibu a identificat foarte bine mișcarea regionalistă alsaciană (și lorenă), care a avut la bază și a fost determinată de vechile tradiții și obiceiuri locale: „Cu toată civilizația lor veche, și poate tocmai pentru aceasta -și cu toate legăturile lor comerciale și culturale cu Franța, aceea ce se chiamă conștiință națională, la ei e ceva cu totul aparte, la ei se vorbește de «sînge Alsacian», de «națiune alsaciană și «lorenă»-ceeace pentru noi e ceva aproape neînțeles pentrucă implică stări de lucruri ce nu se mai intîlnesc întralte locuri [...]" (Ghibu, 1909, p. 8). 
Particularismul alsacian s-a exprimat și s-a dezvoltat în cadrul unei politici autonomiste, care, din punctul de vedere al intelectualului român, a diferit de cea a românilor din Transilvania. Acest tip de particularism nu a ridicat problema radicală a desprinderii teritoriale și politice de Germania. În opinia lui Onisifor Ghibu, procesul de deznaționalizare a fost mult mai amplu în Alsacia-Lorena decît în Transilvania. Spre deosebire de cazul românilor ardeleni, alsacienii și lorenii „apostoli [naţionali] n’au la ei acasă”; de asemenea, „n'au o literatură, n'au literați, n’au presă națională în limba franceză, ziarele pe care le citesc ei „nu sînt redactate într'un spirit național, ca d. ex. foile românești din Ardeal; ele fac politică liberală sau catolică și numai supt acest unghi de vedere sînt privite chestiunile pe care le tratează" (Ghibu, 1909, p. 9, $11)^{12}$.

Onisifor Ghibu a găsit mai multe diferențe decît asemănări între Alsacia-Lorena și Transilvania de la începutul secolului al XX-lea. Dacă în primul caz se poate discuta de manifestarea unei conștiințe regionale, pentru situația românilor ardeleni a fost prioritară exprimarea specificului național. În fapt, problemele specifice alsacienilor din cadrul Germaniei au fost reperate și analizate din perspectiva specifică românilor ardeleni din cadrul Ungariei. Intelectualului român i-a fost greu să înțeleagă cum alsacienii și lorenii au fost mai degrabă animați de o solidaritate regională, și nu de una națională. Alcătuirea etnică a celor două provincii a fost percepută doar din punctul de vedere național francez sau german, calea de mijloc a identității regionale fiind percepută ca ceva grav, anacronic.

„Totuși pe lîngă toate acestea, e ceva tragic, deosebit de tragic în viața acestor Francezi, cari nu se numesc Francezi ci «Germani din teritoriul francez» sau «Alsacieni» și «Lotaringieni». Ei n’au o politică națională, în înțelesul modern al cuvîntului, cum au Polonii, Irlandezii, Finlandezii, Danezii sau Românii din Ungaria cari cer recunoașterea naționalității lor și egala îndreptățire, sub toate raporturile, cu națiunile conducătoare, ei fac cauză comună cu Germanii alsacieni și lotaringieni cu cari au aceleași tradiții locale cu cari vorbesc, cel puțin în parte, acelaș dialect germano-francez și cu care, împreună, cer nu altceva decît recunoașterea Alsaciei-Lorenei ca stat federativ german (Bundesstaat) în cadrele căruia să-și întocmească apoi treburile așa cum cer interesele țerii întregi” (Ghibu, 1909, p. 8).

În cele din urmă, Onisifor Ghibu s-a văzut nevoit să recunoască existența unui puternic sentiment al identităţii regionale, care a animat locuitorii Alsaciei și Lorenei de la începutul secolului al XX-lea. Această identitate regională deosebit de bine conturată, care nu mai ținea în alcătuirea ei interioară de criteriile naționale, atît de dragi lui Ghibu, nu a mai avut aceeași relevanţă pentru cazul Transilvaniei, unde românii şi maghiarii au avut, potrivit intelectualului clujean, interese complet divergente, ireconciliabile și centrifuge $^{13}$. Ghibu a surprins în rîndurile de mai jos formula sintetică a regionalismului în general, potrivit căreia un teritoriu este al acelor oameni care îl locuiesc, indiferent de etnia lor.

„Am zis într'alt loc că locuitorii țării nu privesc țara lor ca un pămînt francez, ci numai ca un pămînt care e al celor ce-l locuiesc: Francezi și Germani, cuprinși deavalma supt numele de Alsacieni și Lotaringieni, de unde și deviza lor, cu care au intrat în luptă: „L’Alsace-Lorraine aus Alsaciens-Lorrains” („Alsacia-Lorena a Alsacienilor-Lorenilor”). Ei nu se mai sbat pentru o realipire către Franța, - gîndul lor se concentrează asupra asigurării neatîrnării țării lor, asupra dobîndirii constituției, ca toate celelalte state germane cari alcătuiesc Imperiul” (Ghibu, 1909, p. $11-12)^{14}$.

\footnotetext{
${ }^{12}$ Afirmații care nu reprezintă în întregime realitatea propriu-zisă. În perioada 1899-1914 a funcționat revista bilingvă și francofilă Revue alsacienne illustrée / Illustrirte elsässische Rundschau.

${ }^{13}$ Opinie care este contrazisă de realitatea propriu-zisă. Au existat intelectuali ardeleni cu o convingere transilvanistă, care au militat pentru conviețuirea celor trei etnii în Transilvania și au susținut ideea unui trecut istoric comun care a unit românii, maghiarii și sașii din interiorul arcului carpatic. Dintre aceștia, cel mai cunoscut este Károly Kós (1883-1977).

${ }^{14}$ Nota acestui paragraf este: „Cea mai puternică dovadă că nimeni nu mai protestează împotriva anexării-a zis în ședința dela 5 Februarie 1908 a Parlamentului din Strasbourg deputatul Gilliot, care a luptat la 1870, vitejește impotriva Germaniloreste faptul că întreaga populație a Alsaciei-Lorenei cere ca statul nostru să fie un stat confederat ca toate celelalte, să fie deci cu un cuvînt, o parte integrată a Imperiului german. Cerem ca să nu mai fim trataţi și mai departe ca Germani de a doua mînă!".
} 


\section{Concluzii}

După toate cele exprimate pînă aici, un lucru este sigur: Alsacia a reprezentat pentru elitele culturale și politice românești din prima jumătate a secolului al XX-lea un model și un reper permanent în disputa privitoare la problemele naționale și regionale/regionaliste cu care s-au confruntat românii din Dubla Monarhie, precum și tînărul Stat român în perioada interbelică. De cele mai multe ori, Transilvania a fost pusă în legătură cu Alsacia, deoarece cele două provincii au traversat etape relativ asemănătoare în ceea ce privește procesul de integrare a teritoriilor de frontieră, cu o încărcătură simbolică și națională mare, în cadrul statelor naționale centralizate. Deși compararea Transilvaniei cu Alsacia a fost explicită din partea românească, din partea franceză lucrurile nu au avut același grad de transparență. Cu toate acestea, am putut constata pe parcursul acestui studiu că și Franța s-a dovedit sensibilă la chestiunea Transilvaniei, cazul propriu alsacian(-loren) fiind destul de asemănător.

Poate cel mai bine au sintetizat situația specială pe care au avut-o Alsacia-în cadrul istoriei Franței și Germaniei-și Transilvania-în cadrul istoriei României și Ungariei-, doi istorici strasbourghezi, care au studiat cu aceeași pasiune atît provincia dintre Vosgi și Rin, cît și provincia intracarpatică. Este vorba de Jean Nouzille (1926-1997) și de Jean-Noël Grandhomme. Primul istoric a surprins foarte bine, încă din subtitlul cărții sale dedicate Transilvaniei, specificul și statutul particular al acestei provincii, determinate mai ales de problema amplasării geografice, între două mari națiuni, care a declanșat deopotrivă nenumărate contacte și conflicte (Nouzille, 1993, passim). Aceeași formulare deosebit de sintetică („Terre de contacts et de conflits") se potrivește la fel de bine și Alsaciei, care a devenit de-a lungul istoriei un adevărat hinterland, un teritoriu tampon între două state în ofensivă națională.

Jean-Noël Grandhomme a surprins mai ales problema identitară a celor care locuiesc cele două provincii de frontieră, care au stat nu doar sub semnul unui sentiment de apartenență identitară eminamente național sau eminamente regional. Ciclul de conferințe inaugurat de istoricul strasbourghez, în anul 2012, a adus încă o perspectivă interpretativă deosebit de importantă pentru subiectul nostru ${ }^{15}$. Formula „les soldats d'entre-deux", pe lîngă puterea ei de sinteză prin care s-a definit complexa situație identitară a tuturor teritoriilor de frontieră unde s-a ridicat deopotrivă problema identităţilor naționale și regionale din timpul Marelui Război, vine să definească încă o dată statutul special pe care l-au avut Alsacia și Transilvania.

\section{Bibliografie}

Ara, A. \& Kolb E. (a cura di). (1995). Regioni di frontiera nell'epoca dei nazionalismi. Alsazia e Lorena / Trento e Trieste, 18701914, Il Mulino Bologna.

Bloch, M. (2006). Pour une histoire comparée des sociétés européennes, în vol. „L'Histoire, la Guerre, la Résistance”, édition établie par A. Becker et É. Bloch, Éditions Gallimard, Paris.

Droz, J. (1960). L’Europe centrale. Évolution historique de l'idée de «Mitteleuropa», Éditions Payot, Paris.

Ghibu, O. (1909). O călătorie prin Alsacia-Lorena. Țara și școlile ei, extras din „Revista Generală a Învățămîntului”, IV, 4-6, București.

Grandhomme, J.-N. (1997). Le soutien de la France à la cause transylvaine jusqu'à l'Union d'Alba Iulia (août 1916-décembre 1918), în „Revue Roumaine d'Histoire”, XXXVI, 3-4, București.

Grandhomme, J.-N. (2000). Les riches heures de la Roumanie à Strasbourg (1923-1926). Le Général Berthelot, Gouverneur militaire, în „Annuaire de la Société Amis du Vieux Strasbourg”, XXVII, Strasbourg.

Grandhomme, J.-N. (2010). 1914-1919: les combattants alsaciens-lorrains entre deux fidélités? Choix individuels et comportements collectifs, în „Autorité, liberté, contrainte en Alsace. Regards sur l'histoire d'Alsace (XIe-XXIe siècles)”, textes réunis par É. Clementz, Éditions Place Stanislas, Nancy.

Grandhomme, J.-N. (2011). Henri-Mathias Berthelot (1861-1931). Du culte de l'offensive à la stratégie globale, Éditions ECPA$\mathrm{D}$, Ivry-sur-Seine.

Muller, C. (2010). Alsace. Une civilisation de la vigne. Du VIII siècle à nos jours, Éditions Place Stanislas, Nancy.

Nouzille, J. (1993). La Transylvanie. Terre de contacts et de conflits, Revue d'Europe Centrale, Strasbourg.

${ }^{15}$ Soldats d'entre-deux. Les Nationalismes minoritaires dans les témoignages des combattants. Europe et Canada (1914-1918), ciclu de conferințe inaugurat la 7 noiembrie 2012, la Universitatea din Strasbourg (vezi și Grandhomme, 2010, p. 259-273). 
Nouzille, J. (1997). Le calvaire des prisonniers de guerre Roumains en Alsace-Lorraine (1917-1918), $2^{\mathrm{e}}$ édition revue et augmentée avec une préface de D. Preda, Éditions Semne '94, Bucarest.

Pomogáts B. (2002). Reconstruirea podurilor (maghiarii și românii) - studii și articole, trad. de A. Pop, Editura Pontfix - Pont Kiadó, Sfintu-Gheorghe - Budapesta.

Le Rider, J. (2001). Europa centrală sau paradoxul fragilitățtii, vol. coord. de D. Chetrinescu și C. Vălcan, pref. de C. Vălcan, postfață de I. Ilian, Editura Polirom, Iași.

Sălăgean, M. (2012). (în colaborare cu A.-M. Stan, E. Cismaş, Sz. Tóth), Universitatea din Cluj intre 1919 şi 1944, în „Istoria Universității «Babeș-Bolyai»”, coord. Ov. Ghitta, Editura Mega, Cluj-Napoca.

Sigmirean, C. (2000). Istoria formării intelectualității românești din Transilvania și Banat în epoca modernă, pref. de N. Bocșan, Presa Universitară Clujeană, Cluj-Napoca.

Sinnhuber, K. A. (1953). Central Europe - Mitteleuropa - Europe Centrale. An Analysis of Geographical Term, în „Transactions and Papers", 20, London.

Trifescu, V. (2010). Introducere în campanilismul alsacian și transilvănean. Hans Haug, Kós Károly și Coriolan Petranu, în „Transilvania”, serie nouă, XXXIX (CXV), 10, Sibiu.

Trifescu, V. (2013). Regionalismul in istoriografia de artă. Valorizarea patrimoniului artistic din Alsacia și Transilvania in prima jumătate a secolului al XX-lea, teză de doctorat, m.s., Universitatea „Babeș-Bolyai” din Cluj-Napoca și Université de Strasbourg.

Trifescu, V. (2014). Aspecte ale identității de frontieră. Regionalism și geografii identitare în Alsacia interbelică, în vol. „Geografii identitare - identități culturale”, coord. P. Puşcaş, V. Trifescu, S. Molnar, V. Ilyes, Presa Universitară Clujeană, Cluj-Napoca.

Veyne, P. (1999). Cum se scrie istoria, trad. de M. Carpov, Editura Meridiane, București. 